\title{
The Crystal Structure of a hCA VII Variant Provides Insights into the Molecular Determinants Responsible for Its Catalytic Behavior
}

\author{
Martina Buonanno ${ }^{1,+}$, Anna Di Fiore ${ }^{1,+}{ }^{+}$Emma Langella ${ }^{1}$ (D), Katia D'Ambrosio ${ }^{1}$, \\ Claudiu T. Supuran ${ }^{2}$ (D), Simona Maria Monti ${ }^{1, *}$ and Giuseppina De Simone ${ }^{1, *}$ \\ 1 Istituto di Biostrutture e Bioimmagini, CNR, Via Mezzocannone 16, 80134 Napoli, Italy; \\ martinabuonanno@gmail.com (M.B.); anna.difiore@cnr.it (A.D.F.); emma.langella@cnr.it (E.L.); \\ Katia.dambrosio@cnr.it (K.D.) \\ 2 Dipartimento Neurofarba, Sezione di Scienze Farmaceutiche e Nutraceutiche, \\ Università degli Studi di Firenze, Via U. Schiff 6, 50019 Florence, Italy; claudiu.supuran@unifi.it \\ * Correspondence: marmonti@unina.it (S.M.M.); gdesimon@unina.it (G.D.S.); \\ Tel.: +39-081-253-4583 (S.M.M.); +39-081-253-4579 (G.D.S.) \\ + These authors contributed equally to the work.
}

Received: 7 May 2018; Accepted: 19 May 2018; Published: 24 May 2018

\begin{abstract}
Although important progress has been achieved in understanding the catalytic mechanism of Carbonic Anhydrases, a detailed picture of all factors influencing the catalytic efficiency of the various human isoforms is still missing. In this paper we report a detailed structural study and theoretical pKa calculations on a hCA VII variant. The obtained data were compared with those already known for another thoroughly investigated cytosolic isoform, hCA II. Our structural studies show that in hCA VII the network of ordered water molecules, which connects the zinc bound solvent molecule to the proton shuttle His64, is altered compared to hCA II, causing a reduction of the catalytic efficiency. Theoretical calculations suggest that changes in solvent network are related to the difference in pKa of the proton shuttle in the two enzymes. The residue that plays a major role in determining the diverse $\mathrm{pKa}$ values of the proton shuttle is the one in position four, namely His for hCA II and Gly for hCA VII. This residue is located on the protein surface, outside of the active site cavity. These findings are in agreement with our previous studies that highlighted the importance of histidines on the protein surface of hCA II (among which His4) as crucial residues for the high catalytic efficiency of this isoform.
\end{abstract}

Keywords: carbonic anhydrases; water network; proton transfer; proton shuttle; catalytic efficiency; $\mathrm{pK}_{\mathrm{a}}$

\section{Introduction}

Carbonic Anhydrases (CAs, EC 4.2.1.1) are ubiquitous metallo-enzymes that are present in most living organisms [1]. Seven genetically distinct families have been identified so far: the $\alpha-, \beta-, \gamma_{-}, \delta_{-}, \zeta_{-}$, $\eta-$, and $\theta$-CAs [1-8]. Human CAs (hCAs) belong to the $\alpha$-class and exist in fifteen isoforms. Although sharing a high level of three-dimensional similarity and a zinc ion in the active site, these isoforms differ in the tissue distribution, catalytic activity and cellular localization. Indeed, five isoforms are cytosolic (CAs I-III, VII and XIII), four are membrane-associated (CAs IV, IX, XII and XIV), two are mitochondrial (CAs VA and VB), and one is a secretory protein present in milk and saliva (CA VI) $[1,9,10]$.

hCAs catalyze a simple but fundamental physiological reaction, the reversible hydration of $\mathrm{CO}_{2}$ to $\mathrm{HCO}_{3}{ }^{-}$and proton, following a two-step mechanism described by Equations (1) and (2) [1]. The first step consists of the nucleophilic attack of the $\mathrm{Zn}^{2+}$-bound hydroxide on $\mathrm{CO}_{2}$ with consequent formation of $\mathrm{HCO}_{3}{ }^{-}$. The binding of $\mathrm{HCO}_{3}{ }^{-}$to the zinc is rather labile, thus it is replaced by a water molecule 
generating the catalytically inactive form of the enzyme EZn ${ }^{2+}-\mathrm{H}_{2} \mathrm{O}$ (Equation (1)). In the second step of the reaction, which is the rate-limiting one, the zinc-bound hydroxide is regenerated through a proton transfer reaction from the zinc-coordinated water molecule to the bulk solvent (B) [11-14].

$$
\begin{gathered}
\mathrm{EZn}^{2+}-\mathrm{OH}^{-}+\mathrm{CO}_{2} \leftrightarrows \mathrm{EZn}^{2+}-\mathrm{HCO}_{3}-\stackrel{\mathrm{H}_{2} \mathrm{O}}{\leftrightarrows} \mathrm{EZn}^{2+}-\mathrm{H}_{2} \mathrm{O}+\mathrm{HCO}_{3}{ }^{-} \\
\mathrm{EZn}^{2+}-\mathrm{H}_{2} \mathrm{O}+\mathrm{B} \leftrightarrows \mathrm{EZn}^{2+}-\mathrm{OH}^{-}+\mathrm{BH}^{+}
\end{gathered}
$$

In the majority of the isoforms, a histidine residue placed in the middle of the active site cavity, namely His64, assists this step acting as a proton shuttle $[15,16]$. Accordingly, isoforms lacking a histidine in position 64 generally show a lower catalytic efficiency [17]. Moreover, the replacement of His64 with Ala in hCA II results in a 10-50-fold decrease of catalysis compared with the wild type enzyme $[16,18]$.

Currently, most of the studies on the catalytic mechanism of hCAs have been performed on the ubiquitous isoform hCA II, which is the most active isozyme. Results demonstrated that the His64 side chain has two conformational states, named in and out. In the in conformation, the imidazole ring points toward the zinc ion, whereas in the out conformation it points out of the active site cavity $[19,20]$. Interestingly, even if it was initially suggested that the His64 conformational mobility was an essential requirement for proton transfer [11], more recent studies have questioned its necessity $[14,21]$. Apart from the presence of His64, other structural features have been recognized as important factors affecting the rate-limiting step of the catalytic reaction [22-25]. In particular, in hCA II the presence of a network of well-ordered water molecules, connecting the $\mathrm{Zn}^{2+}$-bound solvent molecule to His64 (see Figure 1), finely modulates the efficiency of proton transfer during catalysis [14]. Accordingly, site directed mutagenesis of several hCA II residues (Tyr7, Ans62, Asn67, Thr199, and Thr200), which have been shown to interact with these water molecules, caused changes in solvent positions and consequently in the rate of the proton transfer process [26-29].

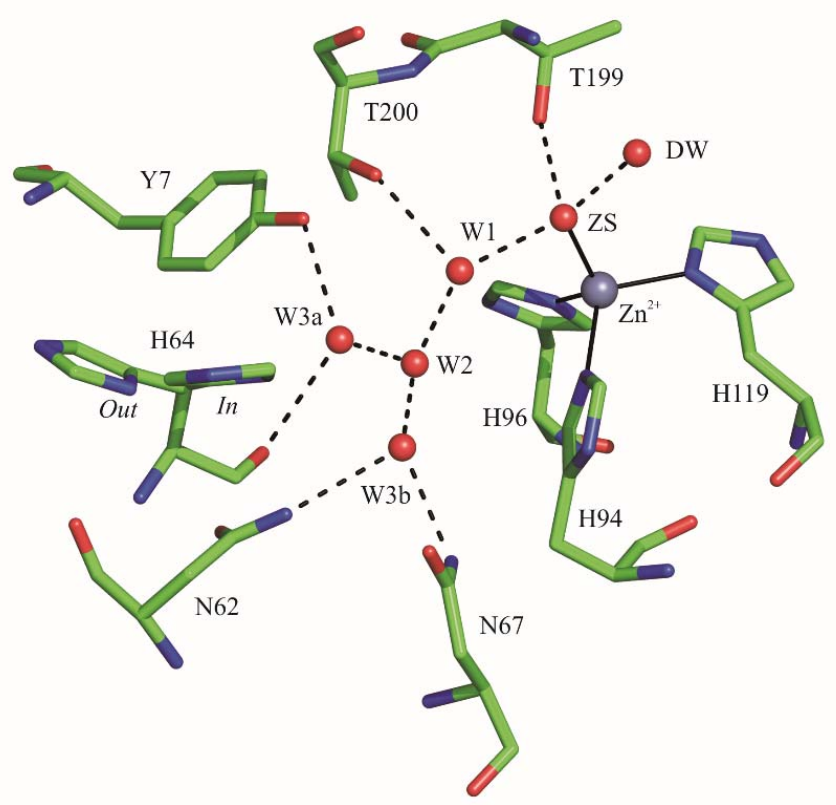

Figure 1. Active site of hCA II (PDB accession code 1TE3) [20] showing the well-ordered water molecules that connect the $\mathrm{Zn}^{2+}$-bound solvent molecule (ZS) to the proton shuttle residue. His64 is present both in its in and out conformation. The solvent molecules are named as reported by Fisher et al., 2005 [20]. The zinc ion coordination and the deep water (DW) are also depicted. Hydrogen bonds are reported as dashed lines. 
Among the cytosolic isoforms, we recently focused our attention on hCA VII [30-35], an enzyme initially detected only in brain, where it functionally participates as a molecular switch for GABAergic excitation $[30,36,37]$. Subsequently, hCA VII was found also in other tissues, such as colon, muscle, and liver [38]. hCA VII has been proposed as a target for CA inhibitors to be used for treatment of epilepsy [37] and chronic neuropathic pain [39]. Recent studies from our group also unveiled for this enzyme a potential role as an oxygen radical scavenger, protecting cells from oxidative damage [33].

hCA VII has been fully characterized from both structural and catalytic viewpoints [32,35]. In particular, crystallographic studies performed on a mutated form of the enzyme in complex with the sulfonamide inhibitor acetazolamide showed that hCA VII structure consists of a central ten-stranded $\beta$-sheet surrounded by several helices and additional $\beta$-strands, as observed for other hCAs [1]. The active site is located in a conical cavity, with the catalytic zinc ion at the bottom [32].

Catalytic assays demonstrated that this enzyme is able to catalyze the $\mathrm{CO}_{2}$ hydration reaction with slightly less efficiency compared to the cytosolic isoform hCA II (hCA VII: $\mathrm{k}_{\text {cat }}=7.9 \times 10^{5} \mathrm{~s}^{-1}$ and $\mathrm{k}_{\mathrm{cat}} / \mathrm{K}_{\mathrm{M}}=7.2 \times 10^{7} \mathrm{M}^{-1} \mathrm{~s}^{-1}$; hCA II: $\mathrm{k}_{\mathrm{cat}}=1.4 \times 10^{6} \mathrm{~s}^{-1}$ and $\mathrm{k}_{\mathrm{cat}} / \mathrm{K}_{\mathrm{M}}=1.5 \times 10^{8} \mathrm{M}^{-1} \mathrm{~s}^{-1}$ ) [35]. This finding was quite surprising considering the high degree of sequence and structural similarity between hCA II and hCA VII. Thus, with the aim to understand the structural factors responsible for the lower catalytic efficiency of hCA VII with respect to hCA II, we performed a crystallographic study of an unbound variant of hCA VII and compared the obtained structure with that of the native hCA II. Theoretical $\mathrm{pK}_{\mathrm{a}}$ calculations of the proton shuttle His64 were also carried out.

\section{Results}

\subsection{Crystallographic Studies}

In a previous study, we reported the bacterial expression, using pGex-6P-1 vector, of a mutated form of hCA VII, named dmCA VII, which contained two amino acid substitutions. In particular, the cysteine residues in position 183 and 217 were mutated to serines. It was demonstrated that the two mutations did not influence the catalytic activity of the enzyme; indeed, the kinetic constants for native hCA VII and dmCA VII were absolutely comparable (dmCA VII: $\mathrm{k}_{\text {cat }}=7.0 \times 10^{5} \mathrm{~s}^{-1}$ and $\mathrm{k}_{\mathrm{cat}} / \mathrm{K}_{\mathrm{M}}=6.5 \times 10^{7} \mathrm{M}^{-1} \mathrm{~s}^{-1}$ ) [35]. dmCA VII was then used for structural studies since it avoided potential crystallization problems caused by the mixture of reduced and oxidized enzyme forms [32].

In this paper, dmCA VII was produced using a different vector, pETM13, which allowed us to successfully express the protein with a C-terminal histidine tag in the soluble fraction of $E$. coli. The purification steps led to obtain the protein with high purity level $(>98 \%)$ and a final yield of $7 \mathrm{mg} / \mathrm{L}$. The enzyme was concentrated at $5 \mathrm{mg} / \mathrm{mL}$ and crystallized, using polyethylene glycol as precipitant, in the space group $\mathrm{P} 2{ }_{1} 2{ }_{1} 2$ with one molecule per asymmetric unit. Using the tagged protein for crystallization experiments, more reproducible results were obtained in comparison with the same trials performed on the protein expressed in the pGex-6P-1 vector.

The structure was determined at $1.91 \AA$ resolution and atomic coordinates were deposited in the Protein Data Bank (PDB) as entry 6G4T. The crystal parameters, data collection, and refinement statistics are listed in Table 1.

The comparative analysis between the obtained structure and the one with the same enzyme crystallized in complex with acetazolamide did not reveal any significant differences [32]. Indeed, the superposition of corresponding C $\alpha$ atoms between the two enzymes leads to an r.m.s.d. of $0.32 \AA$, indicating that the presence of a ligand in the active site did not alter the backbone conformation. The conformation of residues delimiting the active site cavity was also conserved. Interestingly, the proton shuttle His64 was modelled in both structures only in the out conformation; however, in the structure under investigation no evidence of the inward conformation was observed (Figure 2A), whereas some disorder was observed in the case of the inhibited enzyme [32]. 
Table 1. Data collection and refinement statistics.

\begin{tabular}{|c|c|}
\hline Cell Parameter & Value \\
\hline Space group & $\mathrm{P} 2{ }_{1}{ }_{1} 2$ \\
\hline Unit cell parameters $(\AA)$ & $\begin{array}{l}a=66.3 \\
b=89.4 \\
c=44.4\end{array}$ \\
\hline Number of independent molecules & 1 \\
\hline \multicolumn{2}{|l|}{ Data collection statistics } \\
\hline Resolution limits $(\AA)$ & $31.5-1.91$ \\
\hline Wavelength $(\AA)$ & 1.54178 \\
\hline Temperature (K) & 100 \\
\hline Total reflections & 94217 \\
\hline Unique reflections & 20846 \\
\hline Redundancy & 4.5 \\
\hline Completeness (\%) & $98.8(87.3)$ \\
\hline R-merge $(\%) *$ & $0.079(0.520)$ \\
\hline$<\mathrm{I}>/<\sigma(\mathrm{I})>$ & $14.7(2.0)$ \\
\hline \multicolumn{2}{|l|}{ Refinement statistics } \\
\hline Resolution limits $(\AA)$ & $31.5-1.91$ \\
\hline R-work ** $(\%)$ & 19.6 \\
\hline R-free ${ }^{* *}(\%)$ & 24.4 \\
\hline \multicolumn{2}{|l|}{ r.m.s.d. from ideal geometry: } \\
\hline Bond lengths $(\AA)$ & 0.008 \\
\hline Bond angles $\left({ }^{\circ}\right)$ & 1.4 \\
\hline Number of protein atoms & 2063 \\
\hline Number of water molecules & 162 \\
\hline \multicolumn{2}{|l|}{ Average B factor $(\AA 2)$} \\
\hline All atoms & 21.1 \\
\hline Protein atoms & 20.7 \\
\hline Water molecules & 25.6 \\
\hline
\end{tabular}

${ }^{*} \mathrm{R}$-merge $=\Sigma_{\mathrm{hkl}} \Sigma_{\mathrm{i}}|\mathrm{I}(\mathrm{hkl})-<\mathrm{I}(\mathrm{hkl})>| / \Sigma_{\mathrm{hkl}} \Sigma_{\mathrm{i}} \mathrm{I}_{\mathrm{i}}(\mathrm{hkl})$, where $\mathrm{I}_{\mathrm{i}}(\mathrm{hkl})$ is the intensity of an observation and $<\mathrm{I}(\mathrm{hkl})>$ is the mean value for its unique reflection; summations are over all reflections; ${ }^{* *} \mathrm{R}$-work $=\Sigma_{\mathrm{hkl}}|| \mathrm{Fo}(\mathrm{hkl}) \mid-$ $|\mathrm{Fc}(\mathrm{hkl})|\left|/ \Sigma_{\mathrm{hkl}}\right| \mathrm{Fo}(\mathrm{hkl}) \mid$ calculated for the working set of reflections. R-free is calculated as for R-work, but from $5 \%$ of the data that was not used for refinement. Values in parentheses are referred to the highest resolution shell (1.94-1.91 ̊).

In the structure of the unbound dmCA VII, the metal ion maintains the tetrahedral coordination already reported for the inhibited enzyme; in this case the fourth coordination position is occupied by a solvent molecule (ZS), which is connected to His64 through a network of well-ordered water molecules (Figure 2A,B). In detail, $\mathrm{ZS}$ is at hydrogen bond distance from the deep water (DW, the solvent molecule that occupies the $\mathrm{CO}_{2}$ binding pocket) and from the water molecule W1, which in turn interacts with W2 (nomenclature of water molecules refers to that adopted for hCA II by Fisher et al. 2005) [20]. The latter is connected with three other water molecules (W3a-c), W3a is hydrogen bonded with the carbonyl oxygen of His64 and the side chain of Tyr7, W3b interacts with Asn62 and Gln67 side chains, and W3c is at $3.2 \AA$ from the ND1 atom of His64.

A comparative analysis between unbound dmCA VII and native hCA II revealed that the amino acids present within the active site cavity adopt a generally conserved conformation. The most significant difference was observed for the proton shuttle residue which, differently from dmCA VII, in hCA II adopts both the in and the out conformations (Figure 3) [20,40-42]. The network of water molecules, that connects ZS to His64 in both enzymes, also reveals a substantial similarity (Figure 3). The unique significant difference is that in the case of dmCA VII an additional water molecule is 
present, namely W3c, which is located in the same position that in hCA II is occupied by His64 side chain in the in conformation. This molecule is hydrogen bonded to the His64 side chain (Figure 2B).
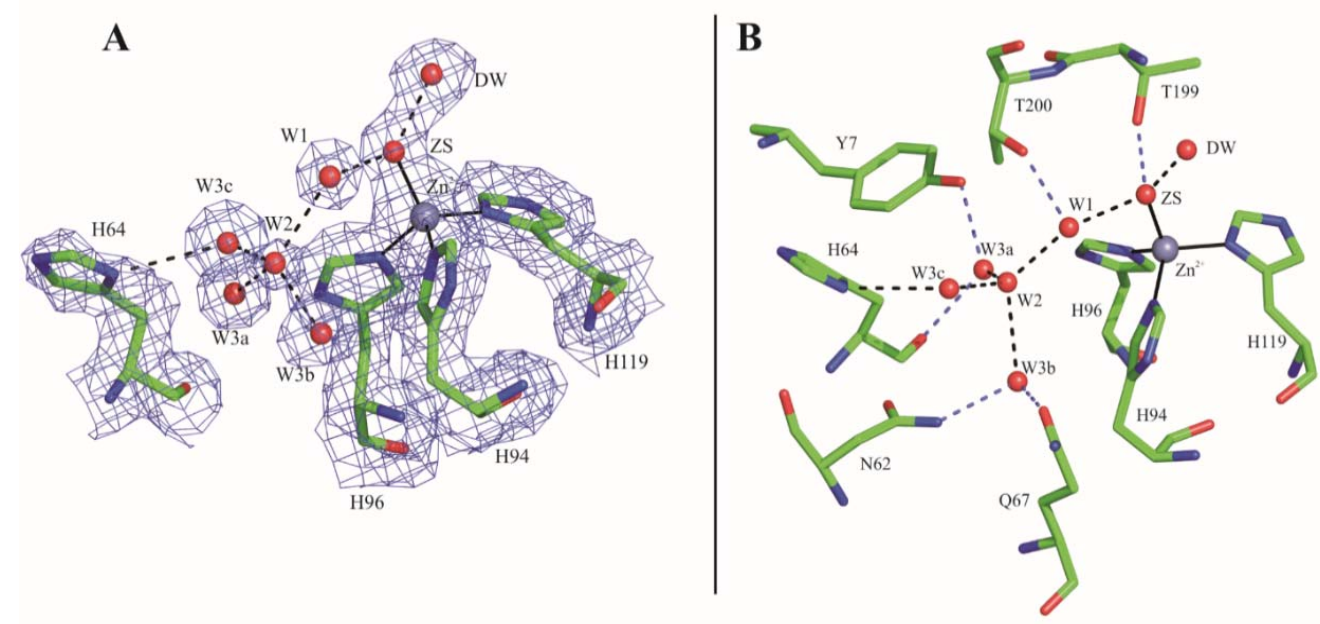

Figure 2. (A) Active site region of dmCA VII, here determined, with associated sigma-A weighted $2|\mathrm{Fo}|-|\mathrm{FC}|$ electron density map contoured at $1.0 \sigma$. The map clearly indicates a unique conformation for His64. (B) Representation of the hydrogen bond network, which connects the $\mathrm{Zn}^{2+}$-bound solvent molecule (ZS) to the proton shuttle. The zinc ion coordination and the deep water (DW) are also reported.

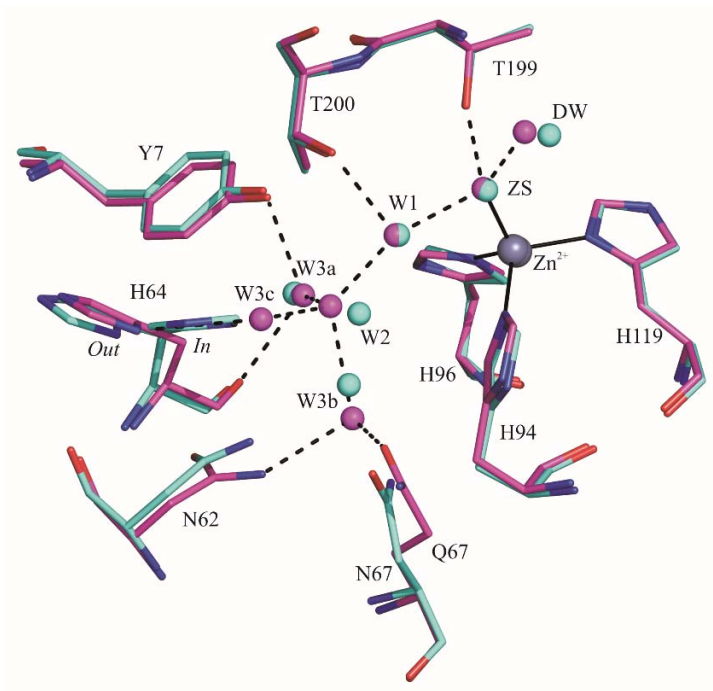

Figure 3. Structural superposition of dmCA VII (colored in magenta) and hCA II (colored in cyan) active site. Hbonds present in dmCA VII are shown as dashed lines.

\section{2. $p K_{a}$ Calculations}

Several papers highlighted a correlation between the $\mathrm{pK}_{\mathrm{a}}$ value of hCA II His64 and conformational preferences of its side chain (see Discussion) [26,29]. Thus, we carried out theoretical predictions of His64 $\mathrm{pK}_{\mathrm{a}}$ value in dmCA VII as well as in hCA II using the PROPKA method [43,44]. Both in and out conformations of His64 present in the native hCA II crystal structure (PDB code 1TE3) [20] were taken into account for calculations. In the case of dmCA VII structure, which shows only His64 out conformation, a model of the in conformation was built using the hCA II structure as template [20]. 
Predicted $\mathrm{pK}_{\mathrm{a}}$ values are shown in Table 2 . These values are significantly lower than those experimentally determined for hCA II His64 [20]. This finding is not surprising, since it is reported in literature $[44,45]$ an underestimation of protein stabilizing interactions for buried residues in PROPKA calculations, which leads to a $\mathrm{pK}_{\mathrm{a}}$ lowering. This is the case of His64 in CA structures, which is $63 \%$ buried in the out conformation and $100 \%$ buried in the in conformation. However, since this effect is present in a comparable manner in all structures under investigation, it is possible to make a relative comparison and to understand the effect of the chemical environment in modulating His $64 \mathrm{pK}_{\mathrm{a}}$ in hCA VII and hCA II.

Table 2. $\mathrm{pK}_{\mathrm{a}}$ predictions of His64 in and out conformations for dmCA VII (this work) and hCA II (pdb code 1TE3) [20] enzymes. Calculations were performed using PROPKA $3.0[43,44]$.

$$
\begin{array}{ccc}
\hline \text { Enzyme } & \multicolumn{2}{c}{\mathbf{p K}_{\mathbf{a}}} \\
\hline & \text { His64 in } & \text { His64 out } \\
\text { dmCA VII } & 3.8^{*} & 4.6 \\
\text { hCA II } & 3.7 & 4.2\left(4.3^{\#}\right) \\
\hline
\end{array}
$$

These calculations reveal that the $\mathrm{pK}_{\mathrm{a}}$ value of His64 is higher in dmCA VII, for both in and out conformations (Table 2). Moreover, for both enzymes, the out conformation displays a higher $\mathrm{pK}_{\mathrm{a}}$ value than the in conformation. Indeed, the His64 in conformation, pointing toward the active site interior, is completely hindered from solvent $(100 \%$ buried) and feels a slight destabilizing charge-charge interaction with $\mathrm{Zn}^{2+}$ ion that further lowers its $\mathrm{pK}_{\mathrm{a}}$ value. On the contrary, the $\mathrm{pK}_{\mathrm{a}}$ of the out conformation in both enzymes is affected by the presence of Lys170, a residue located on the protein surface at the top of the active site cavity (Figure 4).

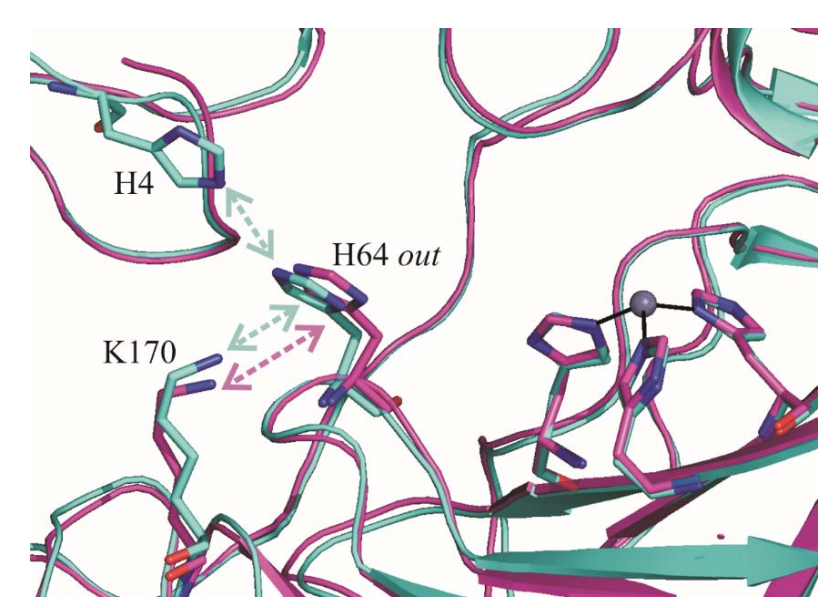

Figure 4. Structural comparison of His64 environment in dmCA VII (magenta) and hCA II (cyan). Residues affecting the $\mathrm{pK}_{\mathrm{a}}$ of His64 out conformation are in sticks and indicated by arrows. The catalytic triad and the zinc ion are also depicted.

In the case of hCA II, there is an additional residue, i.e., His4, which further affects the $\mathrm{pK}_{\mathrm{a}}$ value of the out conformation (Figure 4). Interestingly, this residue is substituted by a Gly in dmCA VII. His4 residue is predicted by PROPKA calculations to titrate at $\mathrm{pH} 6.3\left(\mathrm{pK}_{\mathrm{a}}=6.3\right)$, being completely solvent exposed. The electrostatic interaction between His4 and the nearby His64 residue contributes to hamper the titration of His64 and thus to lower its $\mathrm{pK}_{\mathrm{a}}$ in hCA II. This effect is, however, strongly dependent on the distance between His4 and His64. Since from the analysis of the hCA II structures crystallized in different conditions [20,40,42], it emerged that the side chain of His4 can assume different orientations, we decided to perform $\mathrm{pK}_{\mathrm{a}}$ calculations on different hCA II structures (see Method paragraph) (Table 3). 
The final $\mathrm{pK}_{\mathrm{a}}$ value of hCA II His64 in the out conformation (Table 2) was obtained by averaging over the values reported in Table 3, and further confirms that the $\mathrm{pK}_{\mathrm{a}}$ of His64 is higher in dmCA VII (4.6) than in hCA II (4.3).

Table 3. $\mathrm{pK}_{\mathrm{a}}$ predictions of His64 in out conformation using different crystal structures of hCA II $[20,40,42]$. A and B letters indicate two different conformers of His4 side-chain, when they are present in the same crystal structures.

\begin{tabular}{cc}
\hline hCA II Structures & $\mathbf{p K}_{\mathbf{a}}$ \\
\hline & His64 out \\
1TE3 & 4.2 \\
3KS3 (A) & 4.3 \\
3KS3 (B) & 4.7 \\
2CBA (A) & 3.9 \\
2CBA (B) & 4.2 \\
1TBT & 4.3 \\
1TEQ & 4.4 \\
\hline
\end{tabular}

\section{Discussion}

The aim of this work was to provide insights into the molecular features responsible for the different catalytic activity of hCA II and hCA VII. Two features of these enzymes were thoroughly analyzed and compared: (i) the network of ordered water molecules, connecting the zinc bound solvent molecule and the proton shuttle His64, and (ii) the $\mathrm{pK}_{\mathrm{a}}$ of this residue. Indeed, in previous studies these two features were reported to be important in determining the rate of the proton transfer [14].

hCA II and hCA VII present a high degree of sequence identity (55.7\%), which is mainly localized in the active site region. Indeed, only seven substitutions (S65A, Q67N, D69E, K91I, A135V, S136Q and S204L) are observed among the 23 residues that delimit the active site cavity (Figure 5). Accordingly, the structural superposition of the unbound hCA VII and the native hCA II, crystallized at comparable pH values (PDB codes 1TEQ and 1TE3) [20], reveals a substantial degree of three-dimensional similarity in the conformation of conserved residues belonging to the active sites of the two enzymes. The only notable difference is related to the conformation of His64. Indeed, this residue presents in hCA II both the in and the out conformations, whereas only the out conformation is observed for dmCA VII.

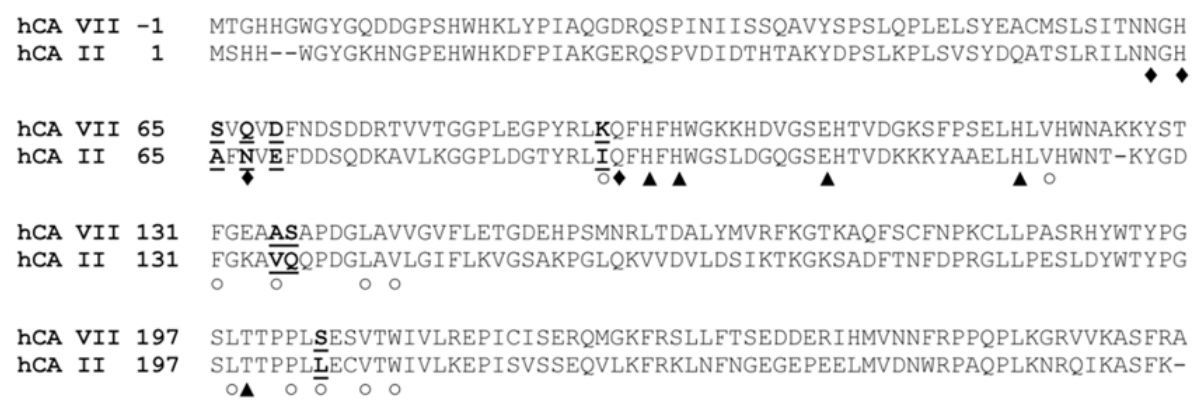

Figure 5. Sequence alignment of hCA VII and hCA II. The catalytic histidines, Thr199 and Glu106 are indicated with a triangle, residues belonging to the hydrophobic region of the active site are indicated with a rhombus, while residues belonging to the hydrophilic one are indicate with a circle. Finally, residues of the active site cavity which are not conserved in the two enzymes are underlined in bold style.

The observation that in dmCA VII only the out conformation is present is quite surprising. Indeed, as mentioned in the Introduction, in many crystallographic structures of hCA II [20,40-42] this residue shows high conformational flexibility and is observed both in the in and out conformation $[19,20]$. The two conformational states are approximately equally populated at 
physiological $\mathrm{pH}$, but a predominance of in conformation is observed at more alkaline $\mathrm{pH}[19,20]$. Since dmCA VII has been crystallized at pH 8.5, in agreement with what was observed for hCA II, a predominant in conformation would have been expected, differently from what experimentally observed. A predominant out conformation of His64 was observed also in the hCA II variants N67L [26], T200S [21], W5H [46], W5E [46], N67Q [47] and N62D [29]. For some of these variants a clear correlation between a higher $\mathrm{pK}_{\mathrm{a}}$ of this residue and the out conformation was observed [26,29]. When this correlation was not present, stabilizing interactions of the imidazole ring (including crystal packing interactions) were utilized to justify the observed out conformation [46]. In agreement with data showing the correlation between the out conformation of His64 and its higher $\mathrm{pK}_{\mathrm{a}}$ values, our theoretical calculations demonstrated that the $\mathrm{pK}_{\mathrm{a}}$ of His64 is higher in dmCA VII than in hCA II.

The different conformational preferences of His64 in hCA II and dmCA VII have important consequences in the solvent structure within the active site cavity. Indeed, the structural comparison between the two enzymes reveals that in the case of dmCA VII an additional water molecule connecting the zinc-bound solvent molecule and His64 is present in the position that in hCA II is occupied by the in conformation of His64. Previous studies reported by Fisher and coworkers [20] proposed that the efficiency of proton transfer is related to the number of water molecules between the $\mathrm{Zn}^{2+}$-bound solvent molecule and the proton shuttle: the smaller the number of connecting water molecules is, the higher the catalytic efficiency will be. These observations were in contrast with the work of Riccardi et al. [48], which suggested that the intramolecular proton transfer is governed by electrostatics and is not sensitive to distance nor number of water molecules bridging the zinc-water and the proton shuttle. Our findings are in agreement with the hypothesis proposed by Fisher. In fact, in our case the higher number of intervening water molecules is associated to a reduced catalytic efficiency of hCA VII with respect to hCA II.

In conclusion, our studies provide a further piece in the complicated puzzle of the hCA catalytic mechanism. In particular, we found that in hCA VII pKa of His64 is higher than in hCA II. This determines a predominant out conformation of its side chain and consequently an altered solvent structure that makes less efficient the catalytic mechanism. Interestingly, a key residue in determining the different $\mathrm{pKa}$ values of the proton shuttle in the two enzymes, is the one in position four, namely His4 for hCA II and Gly4 for hCA VII. Previously reported studies from our group highlighted the crucial role of histidines on the protein surface of hCA II (among which His4) as important in determining the high catalytic efficiency of this isoform $[45,46]$. The studies here reported corroborate this hypothesis; mutagenesis experiments are currently underway in our lab to definitively confirm it.

\section{Materials and Methods}

\subsection{Protein Expression and Purification}

The cDNA encoding the C183S/C217S mutant form of hCA VII, called dmCA VII [32], was PCR amplified using the following site-specific primers with NcoI/XhoI restriction sites:

- F: 5'-CGCGCGCCATGGGCATGACCGGCCACCACG-3'

- R: $5^{\prime}$-CGCGCGCTCGAGGGCCCGGAAGGAGGC-3'

The resulting fragment was ligated into the expression vector pETM13 (a kind gift from EMBL, Heidelberg). The generated plasmid was checked by sequencing and appropriate digestion with restriction enzymes. E. coli BL21 (DE3) cells were transformed with the recombinant construct. The growth was performed at $37{ }^{\circ} \mathrm{C}$. At $\mathrm{OD}_{600}=0.6$, cells were induced by adding IPTG (isopropil- $\beta$-D-1-tiogalactopyranoside) at a final concentration of $0.1 \mathrm{mM}$. The expression of the recombinant protein was carried out at $22{ }^{\circ} \mathrm{C}$ for $16 \mathrm{~h}$. The culture was centrifuged $\left(20 \mathrm{~min}\right.$ at $4{ }^{\circ} \mathrm{C}$ at $27,956 \times g)$ and the pellet stored at $-80^{\circ} \mathrm{C}$.

The lysis of the obtained pellet was performed in PBS 1X (10 mM phosphate buffer, $27 \mathrm{mM}$ potassium chloride and $137 \mathrm{mM}$ sodium chloride, $\mathrm{pH} 7.4$ ), in presence of $1 \mathrm{mM}$ phenylmethanesulfonyl 
fluoride, $5 \mathrm{mg} / \mathrm{mL}$ DNaseI, $0.1 \mathrm{mg} / \mathrm{mL}$ lysozyme and $1.0 \mu \mathrm{g} / \mathrm{mL}$ Aprotinin, Pepstatin and Leupeptin used as protease inhibitors (Apllichem, Darmstadt, Germany). Cells were disrupted by sonication. After centrifugation $\left(30 \mathrm{~min}\right.$ at $4{ }^{\circ} \mathrm{C}$ at $\left.219,126 \times g\right)$, the protein was purified by FPLC, using an AKTA system on a $1 \mathrm{~mL}$ His Trap FF column (GE Healthcare, Little Chalfont, UK), by stepwise elution, according to the manufacturer's instruction (GE Healthcare, Little Chalfont, UK). After elution, dmCA VII enzyme was dialyzed in $20 \mathrm{mM}$ Tris, $100 \mathrm{mM} \mathrm{NaCl}$, pH 8.0 buffer. The protein was further purified by affinity chromatography with p-(aminomethyl) benzene sulfonamide (pAMBS) agarose beads (Sigma, Milan, Italy). Protein purity was assessed on 15\% SDS-PAGE gels, using Biorad Precision Plus Protein All Blue Standards (10-250 kDa) as molecular mass marker.

\subsection{Crystallization and X-ray Data Collection}

hCA VII crystallization conditions were identified using Crystal Screen, Crystal Screen 2 and Index kits from Hampton Research [49,50]. The wells contained $500 \mu \mathrm{L}$ precipitant solution and the drops were composed of $1 \mu \mathrm{L}$ reservoir solution and $1 \mu \mathrm{L}$ protein solution at a concentration of $5 \mathrm{mg} / \mathrm{mL}$ in $20 \mathrm{mM}$ Tris- $\mathrm{HCl}, \mathrm{pH} 8.0,150 \mathrm{mM} \mathrm{NaCl}$. Crystals suitable for X-ray analysis were obtained using $25 \%(w / v)$ polyethylene glycol 3350 in $0.1 \mathrm{M}$ Tris- $\mathrm{HCl}, \mathrm{pH} 8.5$ as precipitant buffer. Crystals appeared in the drops within $48 \mathrm{~h}$ and grew in about 1 week to maximum dimensions of $0.2 \times 0.2 \times 0.2 \mathrm{~mm}^{3}$. A complete dataset was collected at $1.91 \AA$ A resolution from a single crystal at the temperature of $100 \mathrm{~K}$, using a copper rotating-anode generator developed by Rigaku equipped with a Rigaku Saturn CCD detector. Prior to cryogenic freezing, crystals were transferred to the precipitant solution with the addition of $25 \%(w / v)$ glycerol. Diffraction data were indexed, integrated and scaled using the HKL2000 software package [51]. Crystals belonged to the space group $\mathrm{P} 2{ }_{1} 2_{1} 2$ with unit cell dimensions of $\mathrm{a}=66.3 \AA, \mathrm{b}=89.4 \AA, \mathrm{c}=44.4 \AA$ and one molecule for asymmetric unit. Data-collection statistics are reported in Table 1.

\subsection{Structure Determination and Refinement}

The structure of dmCA VII was solved by the molecular replacement technique using the program AMoRe [52] and the atomic coordinates of dmCA VII crystallographic structure in complex with acetazolamide inhibitor (PDB code 3ML5) [32] as a search model. The rotation and translation functions were calculated using data between 15.0 and $3.5 \AA$ A resolution. The one body translation search, using the centered-overlap function (c-o), on the first 50 rotation solutions led to a single solution with a correlation coefficient of 0.672 and an R-factor of 0.327 . Refinement of the structure was performed with CNS $1.3[53,54]$ and model building was performed with O [55]. Several cycles of manual modeling of the structure and positional and temperature factor refinement were carried out to reduce the crystallographic R-work and R-free values (in the 31.5-1.91 $\AA$ resolution range) to 0.196 and 0.244 , respectively. The model stereochemistry was checked using the programs WHATCHECK and PROCHECK [56,57]. The final model contains 2063 protein atoms and 162 water molecules. Coordinates were deposited in the Protein Data Bank (PDB accession code 6G4T).

\subsection{Theoretical $p K_{a}$ Calcuations}

$\mathrm{pK}_{\mathrm{a}}$ values of His64 residue were predicted using PROPKA 3.0 (freely available at http://nbcr222.ucsd.edu/pdb2pqr_2.0.0/) [44]. PROPKA is an empirical $\mathrm{pK}_{\mathrm{a}}$ predicting method, which estimates the shift in the $\mathrm{pK}_{\mathrm{a}}$ arising from hydrogen bonds, relative burial and coulombic interactions $[43,44]$. These contributions are parametrized to fit experimentally measured $\Delta \mathrm{pK}_{\mathrm{a}}$. Calculations were performed using the dmCA VII crystal structure herein reported, and all the available hCA II crystal structures collected in a pH range 7-9 (PDB accession codes 1TE3, 3KS3, 2CBA, 1TBT and 1TEQ) [20,40,42].

Author Contributions: A.D.F., E.L., K.D.A., S.M.M. and G.D.S. conceived and designed experiments; M.B., A.D.F., E.L., K.D.A. performed research; all authors analyzed data; and A.D.F., E.L., K.D.A., S.M.M., C.T.S. and G.D.S. wrote the paper. 
Acknowledgments: We thank Maurizio Amendola and Giosuè Sorrentino for their skillful technical assistance with X-ray measurements.

Conflicts of Interest: The authors declare no conflict of interest.

\section{References}

1. Alterio, V.; Di Fiore, A.; D’Ambrosio, K.; Supuran, C.T.; De Simone, G. Multiple binding modes of inhibitors to carbonic anhydrases: How to design specific drugs targeting 15 different isoforms? Chem. Rev. 2012, 112, 4421-4468. [CrossRef] [PubMed]

2. Del Prete, S.; Vullo, D.; Fisher, G.M.; Andrews, K.T.; Poulsen, S.A.; Capasso, C.; Supuran, C.T. Discovery of a new family of carbonic anhydrases in the malaria pathogen plasmodium falciparum-The eta-carbonic anhydrases. Bioorg. Med. Chem. Lett. 2014, 24, 4389-4396. [CrossRef] [PubMed]

3. Kikutani, S.; Nakajima, K.; Nagasato, C.; Tsuji, Y.; Miyatake, A.; Matsuda, Y. Thylakoid luminal theta-carbonic anhydrase critical for growth and photosynthesis in the marine diatom phaeodactylum tricornutum. Proc. Natl. Acad. Sci. USA 2016, 113, 9828-9833. [CrossRef] [PubMed]

4. Xu, Y.; Feng, L.; Jeffrey, P.D.; Shi, Y.; Morel, F.M. Structure and metal exchange in the cadmium carbonic anhydrase of marine diatoms. Nature 2008, 452, 56-61. [CrossRef] [PubMed]

5. Smith, K.S.; Jakubzick, C.; Whittam, T.S.; Ferry, J.G. Carbonic anhydrase is an ancient enzyme widespread in prokaryotes. Proc. Natl. Acad. Sci. USA 1999, 96, 15184-15189. [CrossRef] [PubMed]

6. Alterio, V.; Monti, S.M.; De Simone, G. Thermal-stable carbonic anhydrases: A structural overview. In Carbonic Anhydrase: Mechanism, Regulation, Links to Disease, and Industrial Applications; Frost, S.C., McKenna, R., Eds.; Springer: Dordrecht, The Netherlands, 2014; Volume 75, pp. 387-404.

7. Alterio, V.; Langella, E.; De Simone, G.; Monti, S.M. Cadmium-containing carbonic anhydrase CDCA1 in marine diatom Thalassiosira weissflogii. Mar. Drugs 2015, 13, 1688-1697. [CrossRef] [PubMed]

8. De Simone, G.; Di Fiore, A.; Capasso, C.; Supuran, C.T. The zinc coordination pattern in the eta-carbonic anhydrase from plasmodium falciparum is different from all other carbonic anhydrase genetic families. Bioorg. Med. Chem. Lett. 2015, 25, 1385-1389. [CrossRef] [PubMed]

9. Supuran, C.T. Carbonic anhydrases: Novel therapeutic applications for inhibitors and activators. Nat. Rev. Drug Discov. 2008, 7, 168-181. [CrossRef] [PubMed]

10. Supuran, C.T.; De Simone, G. (Eds.) Carbonic Anhydrases as Biocatalysts. From Theory to Medical and Industrial Applications; Elsevier: Amsterdam, The Netherlands, 2015.

11. Silverman, D.N.; McKenna, R. Solvent-mediated proton transfer in catalysis by carbonic anhydrase. Acc. Chem. Res. 2007, 40, 669-675. [CrossRef] [PubMed]

12. Aggarwal, M.; Boone, C.D.; Kondeti, B.; McKenna, R. Structural annotation of human carbonic anhydrases. J. Enzym. Inhib. Med. Chem. 2013, 28, 267-277. [CrossRef] [PubMed]

13. Boone, C.D.; Pinard, M.; McKenna, R.; Silverman, D. Catalytic mechanism of alpha-class carbonic anhydrases: $\mathrm{CO}_{2}$ hydration and proton transfer. Subcell. Biochem. 2014, 75, 31-52. [PubMed]

14. Mikulski, R.L.; Silverman, D.N. Proton transfer in catalysis and the role of proton shuttles in carbonic anhydrase. Biochim. Biophys. Acta 2010, 1804, 422-426. [CrossRef] [PubMed]

15. Aggarwal, M.; Kondeti, B.; Tu, C.; Maupin, C.M.; Silverman, D.N.; McKenna, R. Structural insight into activity enhancement and inhibition of H64A carbonic anhydrase II by imidazoles. IUCrJ 2014, 1, $129-135$. [CrossRef] [PubMed]

16. Tu, C.K.; Silverman, D.N.; Forsman, C.; Jonsson, B.H.; Lindskog, S. Role of histidine 64 in the catalytic mechanism of human carbonic anhydrase II studied with a site-specific mutant. Biochemistry 1989, 28, 7913-7918. [CrossRef] [PubMed]

17. Jewell, D.A.; Tu, C.K.; Paranawithana, S.R.; Tanhauser, S.M.; LoGrasso, P.V.; Laipis, P.J.; Silverman, D.N. Enhancement of the catalytic properties of human carbonic anhydrase III by site-directed mutagenesis. Biochemistry 1991, 30, 1484-1490. [CrossRef] [PubMed]

18. Duda, D.; Tu, C.; Qian, M.; Laipis, P.; Agbandje-McKenna, M.; Silverman, D.N.; McKenna, R. Structural and kinetic analysis of the chemical rescue of the proton transfer function of carbonic anhydrase II. Biochemistry 2001, 40, 1741-1748. [CrossRef] [PubMed]

19. Nair, S.K.; Christianson, D.W. Structural properties of human carbonic anhydrase II at $\mathrm{pH} 9.5$. Biochem. Biophys. Res. Commun. 1991, 181, 579-584. [CrossRef] 
20. Fisher, Z.; Hernandez Prada, J.A.; Tu, C.; Duda, D.; Yoshioka, C.; An, H.; Govindasamy, L.; Silverman, D.N.; McKenna, R. Structural and kinetic characterization of active-site histidine as a proton shuttle in catalysis by human carbonic anhydrase II. Biochemistry 2005, 44, 1097-1105. [CrossRef] [PubMed]

21. Krebs, J.F.; Fierke, C.A.; Alexander, R.S.; Christianson, D.W. Conformational mobility of His-64 in the Thr-200 $\rightarrow$ Ser mutant of human carbonic anhydrase II. Biochemistry 1991, 30, 9153-9160. [CrossRef] [PubMed]

22. Taraphder, S.; Maupin, C.M.; Swanson, J.M.; Voth, G.A. Coupling protein dynamics with proton transport in human carbonic anhydrase II. J. Phys. Chem. B 2016, 120, 8389-8404. [CrossRef] [PubMed]

23. Maupin, C.M.; Voth, G.A. Proton transport in carbonic anhydrase: Insights from molecular simulation. Biochim. Biophys. Acta 2010, 1804, 332-341. [CrossRef] [PubMed]

24. Maupin, C.M.; McKenna, R.; Silverman, D.N.; Voth, G.A. Elucidation of the proton transport mechanism in human carbonic anhydrase II. JACS 2009, 131, 7598-7608. [CrossRef] [PubMed]

25. Kim, C.U.; Song, H.; Avvaru, B.S.; Gruner, S.M.; Park, S.; McKenna, R. Tracking solvent and protein movement during $\mathrm{CO}_{2}$ release in carbonic anhydrase II crystals. Proc. Natl. Acad. Sci. USA 2016, 113, 5257-5262. [CrossRef] [PubMed]

26. Fisher, S.Z.; Tu, C.; Bhatt, D.; Govindasamy, L.; Agbandje-McKenna, M.; McKenna, R.; Silverman, D.N. Speeding up proton transfer in a fast enzyme: Kinetic and crystallographic studies on the effect of hydrophobic amino acid substitutions in the active site of human carbonic anhydrase II. Biochemistry 2007, 46, 3803-3813. [CrossRef] [PubMed]

27. Domsic, J.F.; Williams, W.; Fisher, S.Z.; Tu, C.; Agbandje-McKenna, M.; Silverman, D.N.; McKenna, R. Structural and kinetic study of the extended active site for proton transfer in human carbonic anhydrase II. Biochemistry 2010, 49, 6394-6399. [CrossRef] [PubMed]

28. Huang, S.; Sjoblom, B.; Sauer-Eriksson, A.E.; Jonsson, B.H. Organization of an efficient carbonic anhydrase: Implications for the mechanism based on structure-function studies of a T199P/C206S mutant. Biochemistry 2002, 41, 7628-7635. [CrossRef] [PubMed]

29. Zheng, J.; Avvaru, B.S.; Tu, C.; McKenna, R.; Silverman, D.N. Role of hydrophilic residues in proton transfer during catalysis by human carbonic anhydrase II. Biochemistry 2008, 47, 12028-12036. [CrossRef] [PubMed]

30. Montgomery, J.C.; Venta, P.J.; Eddy, R.L.; Fukushima, Y.S.; Shows, T.B.; Tashian, R.E. Characterization of the human gene for a newly discovered carbonic anhydrase, CA VII, and its localization to chromosome 16. Genomics 1991, 11, 835-848. [CrossRef]

31. Earnhardt, J.N.; Qian, M.; Tu, C.; Lakkis, M.M.; Bergenhem, N.C.; Laipis, P.J.; Tashian, R.E.; Silverman, D.N. The catalytic properties of murine carbonic anhydrase VII. Biochemistry 1998, 37, 10837-10845. [CrossRef] [PubMed]

32. Di Fiore, A.; Truppo, E.; Supuran, C.T.; Alterio, V.; Dathan, N.; Bootorabi, F.; Parkkila, S.; Monti, S.M.; De Simone, G. Crystal structure of the C183S/C217S mutant of human CA VII in complex with acetazolamide. Bioorg. Med. Chem. Lett. 2010, 20, 5023-5026. [CrossRef] [PubMed]

33. Del Giudice, R.; Monti, D.M.; Truppo, E.; Arciello, A.; Supuran, C.T.; De Simone, G.; Monti, S.M. Human carbonic anhydrase VII protects cells from oxidative damage. Biol. Chem. 2013, 394, 1343-1348. [CrossRef] [PubMed]

34. Monti, D.M.; De Simone, G.; Langella, E.; Supuran, C.T.; Di Fiore, A.; Monti, S.M. Insights into the role of reactive sulfhydryl groups of carbonic anhydrase III and VII during oxidative damage. J. Enzym. Inhib. Med. Chem. 2017, 32, 5-12. [CrossRef] [PubMed]

35. Truppo, E.; Supuran, C.T.; Sandomenico, A.; Vullo, D.; Innocenti, A.; Di Fiore, A.; Alterio, V.; De Simone, G.; Monti, S.M. Carbonic anhydrase VII is S-glutathionylated without loss of catalytic activity and affinity for sulfonamide inhibitors. Bioorg. Med. Chem. Lett. 2012, 22, 1560-1564. [CrossRef] [PubMed]

36. Ruusuvuori, E.; Li, H.; Huttu, K.; Palva, J.M.; Smirnov, S.; Rivera, C.; Kaila, K.; Voipio, J. Carbonic anhydrase isoform VII acts as a molecular switch in the development of synchronous gamma-frequency firing of hippocampal CA1 pyramidal cells. J. Neurosci. 2004, 24, 2699-2707. [CrossRef] [PubMed]

37. Rivera, C.; Voipio, J.; Kaila, K. Two developmental switches in GABAergic signalling: The $\mathrm{K}^{+}-\mathrm{Cl}^{-}$ cotransporter KCC2 and carbonic anhydrase CA VII. J. Physiol. 2005, 562, 27-36. [CrossRef] [PubMed]

38. Bootorabi, F.; Janis, J.; Smith, E.; Waheed, A.; Kukkurainen, S.; Hytonen, V.; Valjakka, J.; Supuran, C.T.; Vullo, D.; Sly, W.S.; et al. Analysis of a shortened form of human carbonic anhydrase VII expressed in vitro compared to the full-length enzyme. Biochimie 2010, 92, 1072-1080. [CrossRef] [PubMed] 
39. Asiedu, M.; Ossipov, M.H.; Kaila, K.; Price, T.J. Acetazolamide and midazolam act synergistically to inhibit neuropathic pain. Pain 2010, 148, 302-308. [CrossRef] [PubMed]

40. Avvaru, B.S.; Kim, C.U.; Sippel, K.H.; Gruner, S.M.; Agbandje-McKenna, M.; Silverman, D.N.; McKenna, R. A short, strong hydrogen bond in the active site of human carbonic anhydrase II. Biochemistry 2010, 49, 249-251. [CrossRef] [PubMed]

41. Fisher, S.Z.; Maupin, C.M.; Budayova-Spano, M.; Govindasamy, L.; Tu, C.; Agbandje-McKenna, M.; Silverman, D.N.; Voth, G.A.; McKenna, R. Atomic crystal and molecular dynamics simulation structures of human carbonic anhydrase II: Insights into the proton transfer mechanism. Biochemistry 2007, 46, 2930-2937. [CrossRef] [PubMed]

42. Hakansson, K.; Carlsson, M.; Svensson, L.A.; Liljas, A. Structure of native and apo carbonic anhydrase II and structure of some of its anion-ligand complexes. J. Mol. Biol. 1992, 227, 1192-1204. [CrossRef]

43. Li, H.; Robertson, A.D.; Jensen, J.H. Very fast empirical prediction and rationalization of protein $\mathrm{pK}_{\mathrm{a}}$ values. Proteins 2005, 61, 704-721. [CrossRef] [PubMed]

44. Olsson, M.H.; Sondergaard, C.R.; Rostkowski, M.; Jensen, J.H. PROPKA3: Consistent treatment of internal and surface residues in empirical $\mathrm{pK}_{\mathrm{a}}$ predictions. J. Chem. Theory Comput. 2011, 7, 525-537. [CrossRef] [PubMed]

45. Olsson, M.H. Protein electrostatics and $\mathrm{pK}_{\mathrm{a}}$ blind predictions; contribution from empirical predictions of internal ionizable residues. Proteins 2011, 79, 3333-3345. [CrossRef] [PubMed]

46. Mikulski, R.; Domsic, J.F.; Ling, G.; Tu, C.; Robbins, A.H.; Silverman, D.N.; McKenna, R. Structure and catalysis by carbonic anhydrase II: Role of active-site tryptophan 5. Arch. Biochem. Biophys. 2011, 516, 97-102. [CrossRef] [PubMed]

47. Mikulski, R.; West, D.; Sippel, K.H.; Avvaru, B.S.; Aggarwal, M.; Tu, C.; McKenna, R.; Silverman, D.N. Water networks in fast proton transfer during catalysis by human carbonic anhydrase II. Biochemistry 2013, 52, 125-131. [CrossRef] [PubMed]

48. Riccardi, D.; Konig, P.; Guo, H.; Cui, Q. Proton transfer in carbonic anhydrase is controlled by electrostatics rather than the orientation of the acceptor. Biochemistry 2008, 47, 2369-2378. [CrossRef] [PubMed]

49. Cudney, R.; Patel, S.; Weisgraber, K.; Newhouse, Y.; McPherson, A. Screening and optimization strategies for macromolecular crystal growth. Acta Crystallogr. D Biol. Crystallogr. 1994, 50, 414-423. [CrossRef] [PubMed]

50. Jancarik, J.; Kim, S.-H. Sparse matrix sampling: A screening method for crystallization of proteins. J. Appl. Crystallogr. 1991, 24, 409-411. [CrossRef]

51. Otwinowski, Z.; Minor, W. Processing of X-ray diffraction data collected in oscillation mode. Methods Enzymol. 1997, 276, 307-326. [PubMed]

52. Navaza, J. Amore: An automated package for molecular replacement. Acta Crystallogr. Sect. A Found. Crystallogr. 1994, 50, 157-163. [CrossRef]

53. Brunger, A.T.; Adams, P.D.; Clore, G.M.; DeLano, W.L.; Gros, P.; Grosse-Kunstleve, R.W.; Jiang, J.S.; Kuszewski, J.; Nilges, M.; Pannu, N.S.; et al. Crystallography \& NMR system: A new software suite for macromolecular structure determination. Acta Crystallogr. D Biol. Crystallogr. 1998, 54, 905-921. [PubMed]

54. Brunger, A.T. Version 1.2 of the crystallography and NMR system. Nat. Protoc. 2007, 2, 2728-2733. [CrossRef] [PubMed]

55. Jones, T.A.; Zou, J.Y.; Cowan, S.W.; Kjeldgaard, M. Improved methods for building protein models in electron density maps and the location of errors in these models. Acta Crystallogr. Sect. A Found. Crystallogr. 1991, 47 Pt 2, 110-119. [CrossRef]

56. Hooft, R.W.; Vriend, G.; Sander, C.; Abola, E.E. Errors in protein structures. Nature 1996, 381, 272. [CrossRef] [PubMed]

57. Laskowski, R.A.; MacArthur, M.W.; Moss, D.S.; Thornton, J.M. Procheck: A program to check the stereochemical quality of protein structures. J. Appl. Crystallogr. 1993, 26, 283-291. [CrossRef]

(C) 2018 by the authors. Licensee MDPI, Basel, Switzerland. This article is an open access article distributed under the terms and conditions of the Creative Commons Attribution (CC BY) license (http://creativecommons.org/licenses/by/4.0/). 